\section{Oncogenic Ras-induced secretion of IL6 is required for tumorigenesis}

\author{
Brooke Ancrile, Kian-Huat Lim, \\ and Christopher M. Counter ${ }^{1}$
}

Department of Pharmacology and Cancer Biology, Department of Radiation Oncology, Duke University Medical Center, Durham, North Carolina 27710, USA

Ras is mutated to remain in the active oncogenic state in many cancers. As Ras has proven difficult to target therapeutically, we searched for secreted, druggable proteins induced by Ras that are required for tumorigenesis. We found that Ras induces the secretion of cytokine IL6 in different cell types, and that knockdown of IL6, genetic ablation of the $I L 6$ gene, or treatment with a neutralizing IL6 antibody retard Ras-driven tumorigenesis. IL6 appears to act in a paracrine fashion to promote angiogenesis and tumor growth. Inhibiting IL6 may therefore have therapeutic utility for treatment of cancers characterized by oncogenic Ras mutations.

Supplemental material is available at http://www.genesdev.org.

Received March 6, 2007; revised version accepted June 8, 2007.

The small GTPase family of Ras proteins function as GDP/GTP-regulated binary switches that normally relay signals from extracellular stimulus-activated cell surface receptors to diverse cytoplasmic signaling networks in a regulated fashion. Ras is mutated to remain in a stimulus-independent, constitutively active GTP-bound state in one-third of tumors, or if Ras itself is not mutated, the Ras pathway is often inappropriately activated through mutations to upstream receptor tyrosine kinases or downstream components. Such inappropriate activation of Ras provides self-sufficiency in growth signals, leading to increased cell proliferation and survival among other phenotypes characteristic of cancer cells. As such, Ras is a desirable target for cancer therapy, although attempts to inhibit Ras have not yet borne out clinically (Downward 2003). On the other hand, secreted proteins are druggable, typically with neutralizing antibodies (Adams and Weiner 2005). We therefore speculated that inhibiting secreted proteins induced by Ras might block Ras oncogenesis.

The cancer most associated with oncogenic Ras mutations is pancreatic (Downward 2003). Proteins elevated in the serum of pancreatic cancer patients may correspondingly be the product of oncogenic Ras activity. One such protein elevated in pancreatic cancer patients is IL6 (Barber et al. 1999; Wigmore et al. 2002; Ebrahimi et al. 2004). IL6 is a pleiotropic cytokine functioning in in-

[Keywords: Ras; oncogene; IL6; cytokine; cancer] ${ }^{1}$ Corresponding author.

E-MAIL count004@mc.duke.edu; FAX (919) 684-8958.

Article is online at http://www.genesdev.org/cgi/doi/10.1101/gad.1549407. flammation, immunity, bone metabolism, neural development, reproduction, and hematopoiesis (Keller et al. 1996), but it has also been implicated in the etiology of some cancers (Trikha et al. 2003). Given the alluring link of elevated IL6 levels in patients with a cancer characterized by Ras mutations and the observation that Rasinduced secretion of another cytokine, IL8, is important for tumor growth of HeLa cells overexpressing oncogenic Ras (Sparmann and Bar-Sagi 2004), we examined whether IL6 plays any role in Ras-mediated cancers.

\section{Results and Discussion}

\section{Oncogenic Ras ${ }^{G 12 V}$ induces IL6 expression}

Normal human kidney cells genetically transformed with SV40 T/t-Ags, the telomerase catalytic subunit hTERT, and a 4-hydroxytamoxifen (4-OHT) inducible ER:Ras ${ }^{\mathrm{G} 12 \mathrm{~V}}$ fusion protein were assayed for secreted IL6 levels in the absence of 4-OHT, and hence, no ER:Ras ${ }^{\mathrm{G} 12 \mathrm{~V}}$ protein, and presence of $4-\mathrm{OHT}$, and hence, the presence of ER:Ras ${ }^{\mathrm{G} 12 \mathrm{~V}}$, which converts these cells to a tumorigenic state (Lim and Counter 2005). Upon induction of ER:Ras ${ }^{\mathrm{G} 12 \mathrm{~V}}$ by 4-OHT (Fig. 1A, top panel), the level of secreted IL6 was elevated almost 40-fold (Fig. $1 \mathrm{~A}$, bottom panel). Thus, induction of a tumorigenic state by oncogenic Ras is associated with an increase in IL6 secretion.

Ras can elicit very different effects in different cell backgrounds (Shields et al. 2000). To address whether induction of IL6 secretion occurred in other cell types, IL6 secretion was compared with the Ras status and tumorigenic phenotype of four different cell types that retained a constant genetic background $\left(\mathrm{O}^{\prime}\right.$ Hayer and Counter 2006). Both mRNA and protein levels of IL6 were greatly increased in normal primary human kidney cells, fibroblasts, myoblasts, and mammary epithelial cells expressing $\mathrm{T} / \mathrm{t}-\mathrm{Ag}$ and hTERT that were driven to be tumorigenic by ectopic expression of Ras ${ }^{\mathrm{G} 12 \mathrm{~V}}$ compared with the nontumorigenic cells lacking Ras ${ }^{\mathrm{G} 12 \mathrm{~V}}$ (Fig. 1B). Thus, an oncogenic Ras-mediated tumorigenic state is associated with elevated levels of IL6 in multiple cell types.

\section{Ras-induced secretion of IL6 is required for human tumor cell growth in vivo}

To test whether the Ras-induced secretion of IL6 is required for Ras oncogenic function, IL6 levels were stably reduced $>90 \%$ by IL6 short hairpin RNA (shRNA) in the tumorigenic human kidney cells expressing $\mathrm{T} / \mathrm{t}-\mathrm{Ag}$, hTERT, and Ras ${ }^{\mathrm{G} 12 \mathrm{~V}}$ (Fig. 1C). The resultant cells or the scramble control counterpart were then tested for tumor growth in immunocompromised mice. While scramble control cells rapidly formed tumors, reaching maximum tumor volume within $\sim 20$ d, IL6 shRNA-treated cells barely generated palpable masses in this time span $(P<0.001)$ (Fig. 1D,E). Even though tumors eventually did arise (data not shown), IL6 was re-expressed in these tumors (Fig. 1F), strongly suggesting that a loss of IL6 must be overcome for tumor growth.

We validated these results with two more independent IL6 shRNA sequences. Identical to the first IL6 shRNA, knockdown of IL6 by these two other sequences (Fig. 1C) 
A
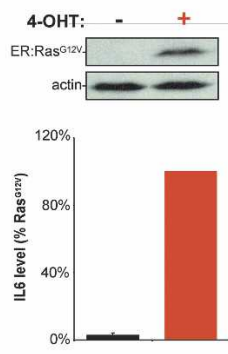

C

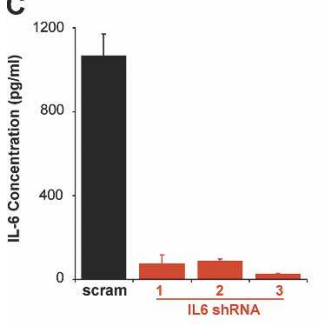

B
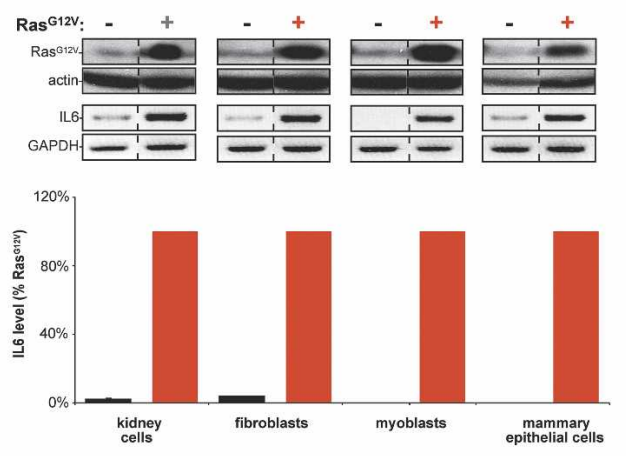

D

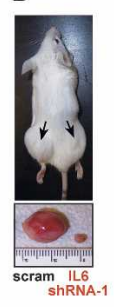

E

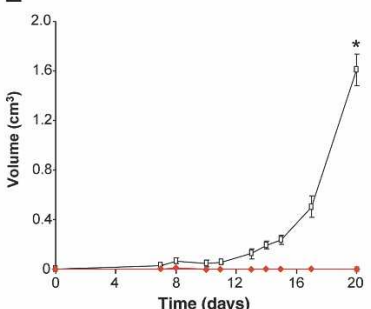

$\mathbf{F}$

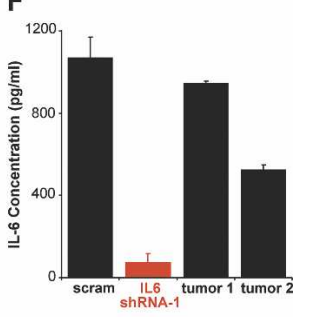

Figure 1. Oncogenic Ras-induced secretion of IL6 is required for Ras-mediated tumorigenesis. (A) IL6-secreted protein levels increase upon activation of Ras. Human kidney cells expressing $\mathrm{T} / \mathrm{t}-\mathrm{Ag}$, hTERT, and ER:Ras ${ }^{\mathrm{G} 12 \mathrm{~V}}$ (and p110-CAAX) were confirmed by immunoblot to up-regulate ER:Ras ${ }^{\mathrm{G} 12 \mathrm{~V}}$ in the presence of 4-OHT (top), which led to elevated levels of IL6 (percent relative to Ras ${ }^{\mathrm{G} 12 \mathrm{~V}}$-expressing cells) present in cell medium as detected by ELISA (bottom). (Actin) Loading control. (B) Oncogenic Ras increases secreted IL6 independent of cell type. The indicated four primary human cell types expressing $\mathrm{T} / \mathrm{t}-\mathrm{Ag}$ and hTERT and, where indicated, also Ras ${ }^{\mathrm{G} 12 \mathrm{~V}}$, as assessed by immunoblot $($ top), were shown to increase the levels of IL6 mRNA, as assessed by RT-PCR (middle), and secreted IL6 protein (percent relative to Ras ${ }^{\mathrm{G} 12 \mathrm{~V}}$. expressing cells), as assessed by ELISA (bottom) upon expression of Ras ${ }^{\mathrm{G} 12 \mathrm{~V}}$. (Actin) Loading control; (GAPDH) RT-PCR control. (C) Primary human kidney cells expressing T/t-Ags, hTERT, Ras ${ }^{\mathrm{G} 12 \mathrm{~V}}$, and shRNA-1, shRNA-2, and shRNA-3, but not a scramble (scram) control sequence, exhibited a decrease in secreted IL6 as assessed by ELISA. (D) Knockdown of IL6 (IL6 shRNA-1) in the aforementioned human kidney cells induced decreased tumor growth, as visualized in a representative mouse (arrow, tumor) or ressected tumors, when compared with scramble control-treated cells (scram). (E) IL6 is required for Ras-driven tumor growth. A plot of tumor volume (cubic centimeters) \pm standard error versus time in days for the aforementioned human kidney cells expressing the scramble control sequence (open box) or the three different IL6 shRNAs (as growth kinetics were identical, tumor growth in mice injected with cells expressing any of the three IL6 shRNAs is shown with one symbol [red diamond]) when injected in mice. $\left({ }^{*}\right) P<0.001(F)$ Two tumors (tumor 1, tumor 2), eventually arising when the aforementioned human kidney cells expressing IL6 shRNA-1 were isolated, were cultured briefly in hygromycin to enrich for tumor cells and assayed for secreted IL6 by ELISA, with the finding that these tumors exhibited increased IL6 compared with the original IL6 shRNA-1 donor cells, almost to the level of scramble (scram) control cells.

blocked tumor growth of the aforementioned Ras ${ }^{\mathrm{G} 12 \mathrm{~V}}$ transformed human kidney cells (Fig. 1E). To address whether IL6 is required for Ras-driven growth independent of cell type, IL6 was knocked down by shRNA (Supplementary Fig. 1A,D) in the aforementioned human fibroblasts and myoblasts engineered to be tumorigenic by the expression of $\mathrm{T} / \mathrm{t}$-Ags, hTERT, and Ras ${ }^{\mathrm{G} 12 \mathrm{~V}}$ (O'Hayer and Counter 2006) and again found to reduce tumor size by at least $97 \%$ compared with scramble control cells (Supplementary Fig. 1B,C,E,F). Knockdown of IL6 thus presents a formidable barrier to Ras-induced human tumor growth of cells derived from different lineages.

\section{IL6 ${ }^{-/-}$mice are highly resistant to spontaneous induced Ras-driven tumors}

To address whether IL6 is also required for Ras-mediated tumor growth in a system that recapitulates the spontaneous process of tumorigenesis, we tested whether $I L 6^{-/}$knockout mice are resistant to carcinogen-induced tumors. Premalignant papillomas with a high level of Ras mutations are induced by topical application of the carcinogen 7,12-Dimethylbenzanthracene (DMBA), followed by repetitive application of 12-O-tetradecanoylphorbol-13-acetate (TPA) (Quintanilla et al. 1986).
Thus, $I L 6^{+/+}$and $I L 6^{-/-}$mice were treated topically with DMBA and then TPA for $20 \mathrm{wk}$, and tumor growth monitored. Tumors appeared within 12 wk of initiation in $I \mathrm{LG}^{+/+}$mice, and by termination of the experiment, $93 \%$ of the mice had tumors, with an average of 2.4 tumors per mouse (Fig. 2A-C). In sharp contrast, tumors appeared 2 wk later in the $I L 6^{-1-}$ mice (Fig. $2 \mathrm{~A}, \mathrm{~B}$ ), and by the termination of the experiment, only $27 \%$ of the mice had tumors (Fig. 2B) and the average number of tumors dropped to 0.5 per mouse $(P<0.01)$ (Fig. 2C). Perhaps most telling, the total tumor volume per mouse at week 20 , a measurement of both the size and number of tumors dropped almost 30 -fold in $I L 6^{-1-}$ mice $(P<0.05)$ (Fig. 2D). In agreement, a 1-wk delay in tumor onset and a $20 \%$ reduction in mice with tumors had been described for DMBA/TPA-treated $I L 6^{-/-}$mice, although in this case, a more aggressive carcinogen protocol was used (Suganuma et al. 2002). Thus, loss of IL6 inhibits spontaneous formation of Ras-driven tumors.

Ras-induced IL6 secretion acts in a paracrine fashion to promote tumor growth

To address how Ras-induced secretion of IL6 promotes tumor growth in vivo, we tested whether the tumor cells 
A
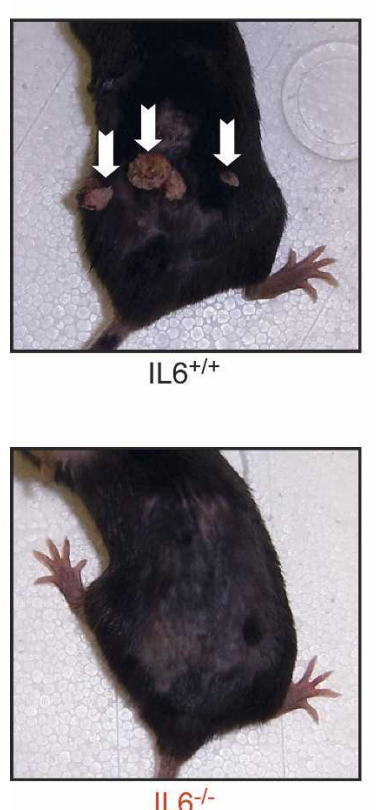

B
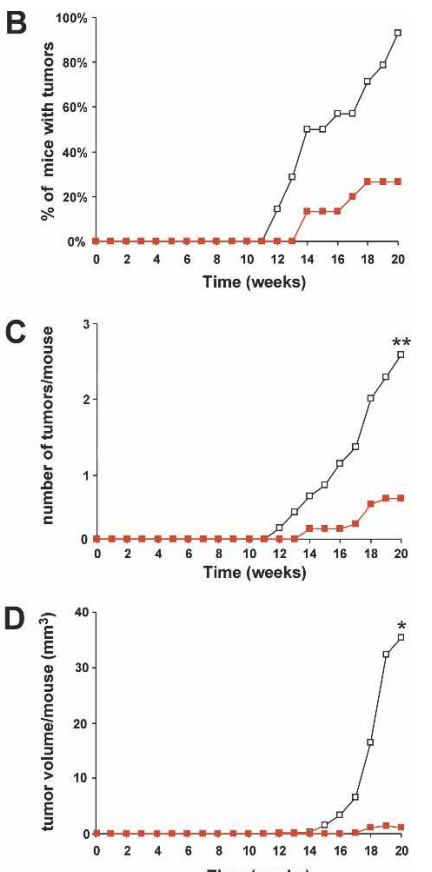

Time (weeks)

Figure 2. $I L 6^{-/-}$mice are resistant to carcinogen-induced skin tumors. Fourteen $I L 6^{+/+}$and $15 I_{L 6^{-/-}}$mice were treated with a single topical application of DMBA, followed 1 wk later by twice-weekly topical applications of TPA for $20 \mathrm{wk}$ to induce skin tumors. $(A)$ Reduction of spontaneous tumors in $\mathrm{ILG}^{-/-}$mice. Representative mice of the indicated genotype at $20 \mathrm{wk}$. (Arrows) Tumors. (B) Reduction in the number of $I L 6^{-/-}$mice having tumors. Percentage of $I L 6^{+/+}$(open box) and $I L 6^{-/-}$(red box) mice with tumors versus time after initial application of DMBA (weeks). (C) Reduction in the number of tumors in $I L 6^{-/-}$mice. Mean number of tumors per $I L 6^{+/+}$ (open box) and $I L 6^{-/-}$(red box) mouse versus time after initial application of DMBA (weeks). $\left.{ }^{\star \star}\right) P<0.01(D)$ Reduction in tumor volume in $I L 6^{-/-}$mice. Mean tumor volume per $I L 6^{+/+}$(open box) and $I L 6^{-/-}$(red box) mouse versus time after initial application of DMBA (weeks). $\left.{ }^{*}\right) P<0.05$.

were themselves the target of IL6. However, we did not find any evidence for autocrine signaling. Ras ${ }^{\mathrm{G} 12 \mathrm{~V}}$-transformed human kidney cells, which require IL6 for tumor growth, do not express detectable IL6 receptor (IL6R) (Fig. 3A), and knockdown of IL6 in these cells did not, when compared with vector control cells, have any effect on cell proliferation under normal serum (Fig. 3B, top panel) or in the stress condition of low serum (Fig. 3B, middle panel) or growth in soft agar (Fig. 3C), nor did addition of exogenous IL6 foster the growth of the same cells in the absence of Ras (Fig. 3B, bottom panel). We thus explored the possibility that Ras-induced secretion of IL6 acts in a paracrine fashion to promote Ras tumorigenesis. Immunohistological staining revealed that tumors eventually arising from IL6 shRNA-treated $\mathrm{Ras}^{\mathrm{G} 12 \mathrm{~V}}$-transformed human kidney cells did not exhibit any gross histological differences, or changes in cell proliferation, as assessed by Ki67 and phospho-histone H3 staining, or apoptosis, as detected by the TUNEL assay, compared with scramble control tumors $(P>0.05)$ (Fig. 3D). This could mean that either loss of IL6 has no effect on apoptosis or proliferation, or that by the time we are able to study these tumors, the observed reactivation of IL6 (Fig. 1F) masked these effects. Nevertheless, we did find that CD31-positive (endothelial) cells were reduced

almost 18-fold in IL6 shRNA-treated tumors $(P<0.01)$ (Fig. 3D). In agreement, IL6 has been shown to promote angiogenesis (Cohen et al. 1996; Wei et al. 2003; Huang et al. 2004; Loeffler et al. 2005; Nilsson et al. 2005). However, endothelial cells typically do not express detectable levels of IL6R (Supplementary Fig. 2) (Romano et al. 1997) or respond to IL6 (Podor et al. 1989; Sironi et al. 1989), arguing that the reduction of CD31-positive cells by knocking down IL6 in tumorigenic cells is indirect. This paracine effect must also be local, as tumors arising

A

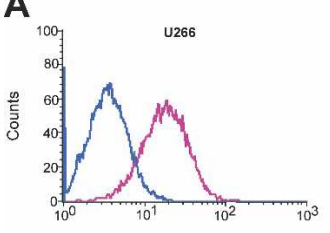

C
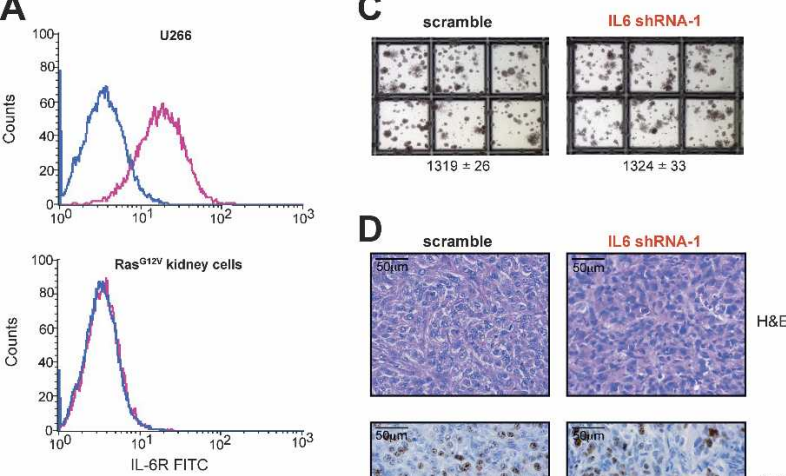

B
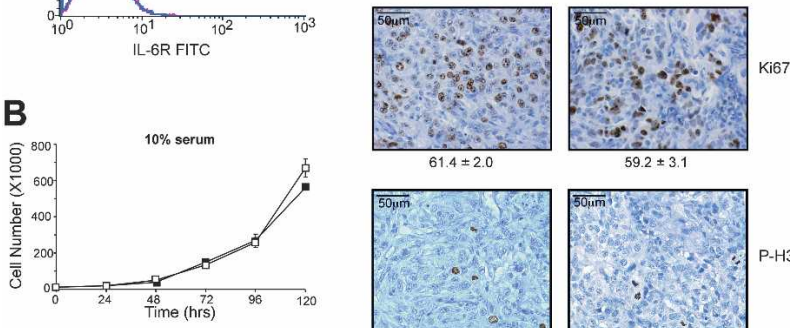

$61.4 \pm 2.0$

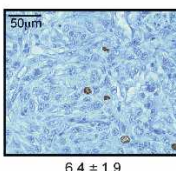

$592 \pm 3.1$
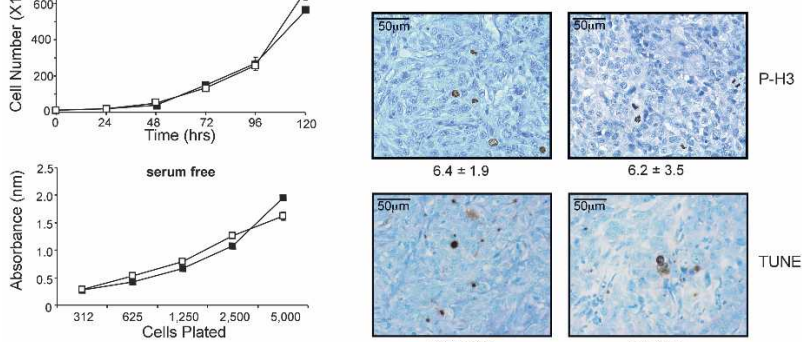

$6.4 \pm 1.9$

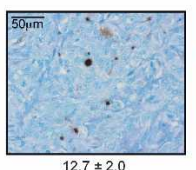

$6.2 \pm 3.5$
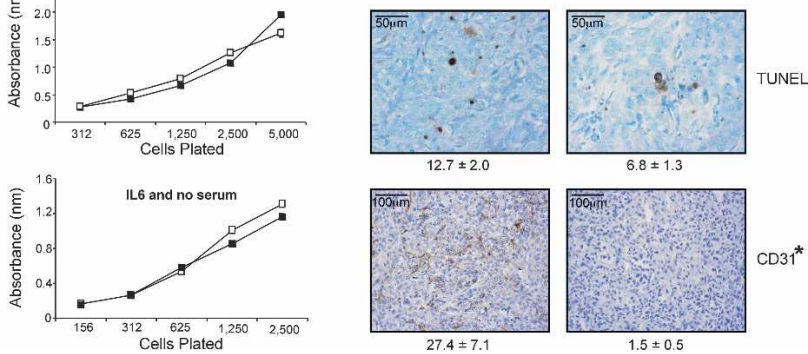

Figure 3. IL6 acts in a paracrine manner to promote angiogenesis. (A) Detection of IL6R (pink profile) by flow-cytometric analysis in positive control U266 cells (top graph), but not Ras ${ }^{\mathrm{G} 12 \mathrm{~V}}$-transformed human kidney cells (bottom graph). No antibody (blue profile serves as a negative control. (B) IL6 does not alter the growth of $\mathrm{Ras}^{\mathrm{G} 12 \mathrm{~V}}$-transformed human kidney cells. Absorbance \pm standard error versus time (days) as measured by the MTT assay of Ras ${ }^{\mathrm{G} 12 \mathrm{~V}}$. transformed human kidney cells stably expressing IL6 shRNA-1 (black box) or the appropriate scramble sequence (open box) cultured in $10 \%$ serum (top) or serum-free (middle) medium, or the same kidney cells lacking Ras ${ }^{\mathrm{G} 12 \mathrm{~V}}$ plated at the indicated densities in serumfree medium (black box) or serum-free medium containing $100 \mathrm{pg} /$ $\mathrm{mL}$ IL6 (open box). (C) Similar anchorage-independent growth of $\mathrm{Ras}^{\mathrm{G} 12 \mathrm{~V}}$-transformed human kidney cells stably expressing IL6 shRNA-1 versus the appropriate scramble sequence. Average number of colonies \pm standard error calculated from three independent experiments conducted in triplicate. $(D)$ Loss of IL6 inhibits angiogenesis. Tumors from Ras ${ }^{\mathrm{G} 12 \mathrm{~V}}$-transformed human kidney cells stably expressing IL6 shRNA-1 or the appropriate scramble sequence were excised, formalin-fixed, and stained for H\&E or assayed for Ki67, phospho-histone H3 (P-H3), TUNEL, or CD31-positive (dark brown) cells. (Bottom) Average number of marker-positive cells \pm standard deviation from five independent fields of two to four different tumors. $\left.\left({ }^{*}\right) P<0.01\right)$ 
A

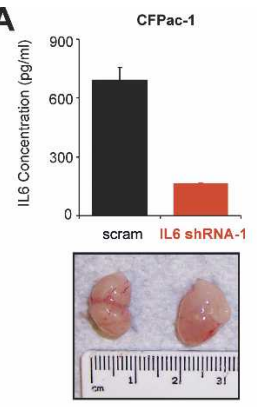

B

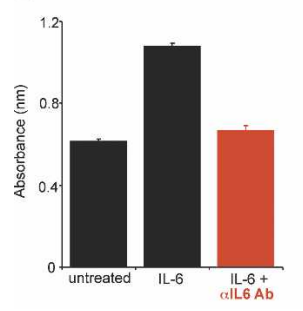

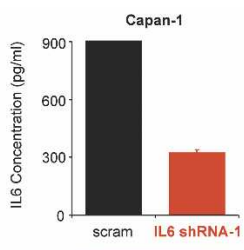
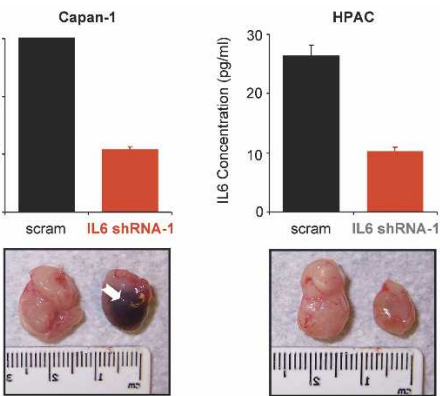

C

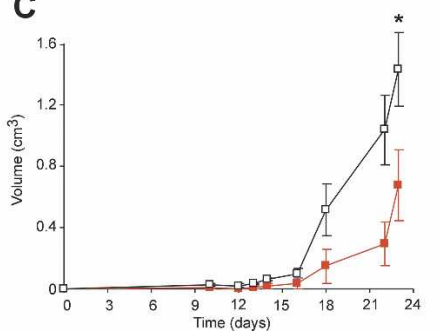

tumor growth. As IL6 is a secreted protein, it is amendable to targeting by neutralizing antibodies. Moreover, such an antibody is tolerated in humans (Trikha et al. 2003). Thus, we tested whether a neutralizing IL6 antibody could inhibit the tumor growth of the Ras ${ }^{\mathrm{G} 12 \mathrm{~V}}$-transformed human kidney cells. We first confirmed that such an antibody effectively neutralized IL6 in a biological assay. Addition of the neutralizing IL6 antibody to culture medium reduced the IL6-dependant growth of B9 cells to the same level as cells that were not induced by IL6 (Fig. 4B). Next, mice pretreated with either the IL6-neutralizing antibody or a control IgG antibody were injected with $\mathrm{Ras}^{\mathrm{G} 12 \mathrm{~V}}$-transformed human kidney cells, and then treated again every $3 \mathrm{~d}$ by intratumor injections of either the anti-IL6 or control antibody. Tumors in mice treated with the control IgG antibody first appeared at week 2 and reached maximum tumor volume by day 23 . This growth was retarded in the IL6-neutralizing antibody treatment group, and tumors were approximately half the size $(P<0.01)$ of control tumors (Fig. $4 \mathrm{C}, \mathrm{D})$. Consistent with these data, anti-IL6 antibodies have been reported to reduce the tumor growth of prostate cancer cells (Smith and Keller 2001; Wallner et al. 2006). These experiments suggest the intriguing possibility that IL6-neutralizing antibodies may have therapeutic value in the treatment of Ras-driven cancers. taneously into the flanks of mice. (Arrow) Region of necrosis. (B) Neutralization of IL6 activity by an anti-IL6 antibody ( $\alpha$ IL6 Ab). Cell numbers as measured by average absorbance \pm standard error using the MTT assay $48 \mathrm{~h}$ after B9 cells were plated in serum-free medium (untreated), in the presence of IL6 to stimulate cell proliferation (IL6) or in the presence of IL6 and $\alpha \mathrm{IL} 6 \mathrm{Ab}(\mathrm{IL} 6+\alpha \mathrm{IL} 6 \mathrm{Ab}) .(C)$ An IL6-neutralizing antibody inhibits Ras-driven tumor growth. Tumor volume (cubic centimeters) \pm standard error versus time (days) of Ras ${ }^{\mathrm{G} 12 \mathrm{~V}}$-transformed human kidney cells growing in mice injected at the tumor site every $3 \mathrm{~d}$ with 100 $\mu \mathrm{g}$ of either the $\operatorname{IgG}_{1}$ control antibody (black box) or the IL6-neutralizing antibody (red box). $\left.{ }^{*}\right) P<0.01$. (D) Representative tumors of Ras ${ }^{\mathrm{G} 12 \mathrm{~V}}$-transformed human kidney cells growing in mice injected every $3 \mathrm{~d}$ with $100 \mu \mathrm{g}$ of either the $\mathrm{IgG}_{1}$ control antibody (control $\mathrm{Ab}$ ) or the IL6-neutralizing antibody ( $\alpha \mathrm{IL} 6 \mathrm{Ab}$ ).

from scramble control cells on one flank of the mice failed to promote tumorigenic growth of IL6 shRNAtreated cells on the opposite flank (Fig. 1D).

\section{IL6 as a target for cancer therapy}

To expand our studies to more clinically relevant settings, we tested whether stable knockdown of IL6 (Fig. $4 \mathrm{~A}$, top panels) inhibited the tumorigenic growth in the human pancreatic cancer cell lines CFPac-1, Capan-1, and HPAC that contain an oncogenic K-Ras allele (Kita et al. 1999; Moore et al. 2001; Lim et al. 2006), as such cell lines better model the genetic chaos of human cancers that is thought to underlie the variability in the effectiveness of cancer therapies. While knockdown of IL6 had no obvious effect on CFPac-1 cells, it did cause necrosis in the tumors arising from Capan- 1 cells and retarded the tumor growth of HPAC cells compared with scramble control-treated cells (Fig. 4A, bottom panels). Thus, IL6 is important for tumorigenic growth in two of the three tested human mutant K-Ras-positive cancer cell lines, suggesting that an anti-IL6 therapy could be effective in the heterogeneous situation of human cancers.

We next tested whether a more clinically relevant mode of inhibiting IL6 function could impede Ras-driven

\section{Summary}

We show that oncogenic Ras induces the secretion of the cytokine IL6 from a variety of cell types, and that knockdown or genetic ablation of IL6 thwarts Ras-mediated tumor growth of human tumor cell lines and chemical carcinogeninduced tumors. IL6 is thus a bona fide downstream effector of oncogenic Ras that promotes the tumorigenic effects of Ras. IL6 can also act upstream of Ras (Rowley and Van Ness 2002) and, correspondingly, the tumor-promoting effects of IL6 can be context dependant. Nevertheless, in the case of the tested oncogenic Ras-driven tumor cells, IL6 acts downstream from Ras in a paracrine fashion to promote angiogenesis. Overexpression of oncogenic Ras in the tumorigenic HeLa cancer cell line also induced the secretion of a different cytokine IL8, and inhibiting IL8 reduced tumor growth of these cells and the number of CD31-positive cells in a tumor (Sparmann and Bar-Sagi 2004). Like IL6, IL8 was also secreted upon expression of Ras in different human cell types (Supplementary Fig. 3). Thus, Ras-induced secretion of multiple cytokines may underlie the ability of this oncogene to potently induce angiogenesis. Secreted proteins that promote angiogenesis have been successfully inhibited with neutralizing antibodies with desirable clinical outcomes in the treatment of many different human cancers (Adams and Weiner 2005). Consistent with this promising therapeutic strategy to target angiogenesis, and the dependence of oncogenic Rasdriven tumorigenesis on IL6 for angiogenesis, we demonstrate that an IL6-neutralizing antibody inhibits Rasdriven tumor growth. IL6 is thus a druggable protein that holds promise as a target for the treatment of Ras-driven cancers. 


\section{Materials and methods}

\section{Retroviral vectors}

pBabepuro, pBabepuro-H-Ras ${ }^{\mathrm{G} 12 \mathrm{~V}}$, and pBabepuro-ER:Ras ${ }^{\mathrm{G} 12 \mathrm{~V}}$ were previously described (Lim and Counter 2005). IL6 shRNA-1, shRNA-2, and shRNA-3, and scramble control sequences $\left(5^{\prime}\right.$-AGATGGATGCTTC CAATCTGG-3' ' 5'-AAGGCAAAGAATCTAGATGCA-3', 5'-AGACAT GTAACAAGAGTAA-3', and 5'-AGACGGAGGCTTACAGTCTGG-3' respectively) were cloned into pSUPER-RETRO-PURO.

Cell lines

Human (embryonic) kidney cells, BJ fibroblasts, mammary epithelial cells, and skeletal muscle myoblasts stably expressing the early region of SV40 (which produce the proteins T-Ag and $\mathrm{t}-\mathrm{Ag}$ ); hTERT; and either $\mathrm{H}-\mathrm{Ras}^{\mathrm{G} 12 \mathrm{~V}}$ or no transgene (O'Hayer and Counter 2006) were stably infected with retroviruses generated from the indicated vectors to generate polyclonal populations as previously described $\left(\mathrm{O}^{\prime}\right.$ Hayer and Counter 2006). The ER:Ras ${ }^{\mathrm{G} 12 \mathrm{~V}}$-expressing tumor kidney cells also expressed p110-CAAX for unrelated reasons (Lim and Counter 2005). B9 cells (Aarden et al. 1987) were a kind gift of Peter Lansdorp (University of British Columbia, Vancouver, BC, Canada). U266 cells were obtained from American Type Culture Collection. HMVECs were a kind gift of Xiao-Fan Wang (Duke University Medical Center, Durham, NC).

$R T-P C R$

Total RNA was isolated, reverse-transcribed with an oligodT primer, and PCR-amplified with the primers 5'-ATGTAGCCGCCCCACACAGA-3' and 5'-CATCCATCTTTTTCAGCCAT-3' to detect IL6, and 5'-GAAG GTGAAGGTCGGAGACAA- 3 ' and 5'-GCAGAGGGGGCAGAGATGA T-3' to detect GAPDH, using a previously described protocol (Hamad et al. 2002). Cycle number varied between 25 and 40 cycles, depending on cell type and transcript.

Immunoblot

Lysates from the described cell lines were immunoblotted with the primary antibody $\alpha$-pan-Ras (Oncogene) or $\alpha$-actin C-2 (Santa Cruz Biotechnology) using standard methods.

IL6R detection

Cells $\left(2 \times 10^{6}\right)$ were incubated with $20 \mu \mathrm{L}$ of IL6R FITC-conjugated antibody (Abcam) in 3\% BSA-PBS for $1 \mathrm{~h}$ at $4^{\circ} \mathrm{C}$. Cells were then washed three times in PBS and IL6R-positive cells were detected by flow cytometry.

\section{ELISA}

Cells were plated at $\sim 80 \%$ confluency. Twenty-four hours later, cells were washed three times with PBS and cultured in serum-free medium, and $48 \mathrm{~h}$ later, cells were collected and analyzed in duplicate with a human IL6 or IL8 ELISA Kit (R\&D Systems). Results are reported as means \pm standard deviation.

Cell proliferation

Cells $\left(1 \times 10^{4}\right.$ per 6-cm dish) were seeded in triplicate, and viable trypan blue-negative cells were counted daily for $5 \mathrm{~d}$. To measure cell proliferation rate under stress conditions, cells were plated at varying densities in a 96-well plate. Twenty-four hours later, medium was replaced with serum-free medium. Four days later, $50 \mu \mathrm{L}$ of $5 \mathrm{mg} / \mathrm{mL}$ 3-(4,5-Dimethyl2-thiazolyl)-2,5-diphenyl-2H-tetrazolium bromide (MTT; Sigma) was added to each well, and $4 \mathrm{~h}$ later, medium was aspirated and cells were resuspended in $200 \mu \mathrm{L}$ of DMSO. Absorbencies were recorded at $540 \mathrm{~nm}$. IL6 antibody neutralization was assayed by seeding $3 \times 10^{4}$ B9 cells per well in a 96-well plate in medium supplemented with $10 \mathrm{pg} / \mathrm{mL}$ human IL6 and $0.04 \mathrm{ug} / \mathrm{mL}$ monoclonal anti-human IL6 antibody (R\&D Systems), which was preincubated to allow binding of the antibody to the cytokine. Forty-eight hours later, $10 \mu \mathrm{L}$ of $5 \mathrm{mg} / \mathrm{mL}$ MTT was added per well. Four hours later, $50 \mu \mathrm{L}$ of $20 \% \mathrm{SDS} / 50 \%$ DMF was added per well, and $24 \mathrm{~h}$ later, the absorbencies at $570-650 \mathrm{~nm}$ were measured.

Soft agar

Of the indicated cells, $5 \times 10^{4}$ cells were suspended in soft agar in triplicate three times independently, and colonies $>30$ cells were scored after 3 wk, as previously described (Cifone and Fidler 1980; Hamad et al. 2002).
Tumor growth

Cells $\left(1 \times 10^{7}\right)$ mixed with Matrigel were injected subcutaneously into one or both flanks of SCID/beige mice for a total of four injections per cell line, after which tumor volumes were determined at regular intervals as described previously (Hamad et al. 2002). In cases in which tumorderived cells were retested for IL6 levels, tumors were established in culture under hygromycin selection to enrich for tumor cells as previously described (Lim and Counter 2005). For antibody neutralization of IL6, four animals were pretreated with an injection of $100 \mu \mathrm{g}$ per mouse IL6-neutralizing antibody (MAB206; R\&D Systems) or isotype control antibody (R\&D Systems) $2 \mathrm{~d}$ prior to tumor cell injection. Starting $1 \mathrm{~d}$ after tumor cell injection, mice were treated with neutralizing IL6 antibody or control antibody every $3 \mathrm{~d}$ at the tumor site. For chemical carcinogenesis, the backs of 15 control $\left(\mathrm{IL}^{+/+}\right) \mathrm{C} 57 \mathrm{BL} / 6 \mathrm{~J}$ mice and $15 \mathrm{ex}-$ perimental $\left(I L 6^{-/-}\right) \mathrm{C} 57 \mathrm{BL} / 6 \mathrm{~J}$ mice, in which both alleles of IL6 were disrupted (B6.129S2-IL6 $6^{\text {tm1Kopf } / J) ~(K o p f ~ e t ~ a l . ~ 1994) ~(J a c k s o n ~ L a b o r a t o r y) ~}$ were shaved, and the following day, $150 \mu \mathrm{L}$ of $125 \mu \mathrm{g} / \mathrm{mL}$ DMBA (Sigma) in DMSO were applied topically, followed 1 wk later by twice-weekly topical applications of $150 \mu \mathrm{L}$ of $10^{-4} \mathrm{M}$ TPA (Sigma) in DMSO for $20 \mathrm{wk}$. One $\mathrm{ILG}^{+/+}$mouse died at week 11 for unrelated reasons and was excluded from analysis. Tumor number and size were recorded weekly. Student's $t$-test was used to compare tumor growth in the various models. The differences between means were considered significant if $P<0.05$. All procedures with mice were done under an Institutional Animal Care and Use Committee-approved protocol.

\section{Immunohistochemistry}

Excised tumors were fixed in formalin and sectioned. H\&E staining, Ki67 ( $\alpha$ Ki-67 Ab, Zymed), phospho-histone H3 ( $\alpha$ phospho-Histone H3 [Ser10] $\mathrm{Ab}$; Upstate Biotechnology), and CD31 ( $\alpha$-PECAM-1 Ab; Santa Cruz Biotechnology) immunohistochemistry, and TUNEL assay (Apoptag Plus Peroxidase Apoptosis Detection Kit; Chemicon) were preformed using standard protocols.

\section{Acknowledgments}

We thank the Counter laboratory for thoughtful discussions. This work was supported by NIH grant CA94184. C.M.C. is a Leukemia and Lymphoma Scholar, K.-H.L. is a Department of Defence Breast Cancer Research Predoctoral Scholar.

\section{References}

Aarden, L.A., De Groot, E.R., Schaap, O.L., and Lansdorp, P.M. 1987. Production of hybridoma growth factor by human monocytes. Eur. I. Immunol. 17: 1411-1416.

Adams, G.P. and Weiner, L.M. 2005. Monoclonal antibody therapy of cancer. Nat. Biotechnol. 23: 1147-1157.

Barber, M.D., Fearon, K.C., and Ross, J.A. 1999. Relationship of serum levels of interleukin-6, soluble interleukin-6 receptor and tumour necrosis factor receptors to the acute-phase protein response in advanced pancreatic cancer. Clin. Sci. 96: 83-87.

Cifone, M.A. and Fidler, I.J. 1980. Correlation of patterns of anchorageindependent growth with in vivo behavior of cells from a murine fibrosarcoma. Proc. Nat1. Acad. Sci. 77: 1039-1043.

Cohen, T., Nahari, D., Cerem, L.W., Neufeld, G., and Levi, B.Z. 1996 Interleukin 6 induces the expression of vascular endothelial growth factor. J. Biol. Chem. 271: 736-741.

Downward, J. 2003. Targeting RAS signalling pathways in cancer therapy. Nat. Rev. Cancer 3: 11-22.

Ebrahimi, B., Tucker, S.L., Li, D., Abbruzzese, J.L., and Kurzrock, R. 2004. Cytokines in pancreatic carcinoma: Correlation with phenotypic characteristics and prognosis. Cancer 101: 2727-2736.

Hamad, N.M., Elconin, J.H., Karnoub, A.E., Bai, W., Rich, J.N., Abraham, R.T., Der, C.J., and Counter, C.M. 2002. Distinct requirements for Ras oncogenesis in human versus mouse cells. Genes \& Dev. 16: 2045-2057.

Huang, S.P., Wu, M.S., Shun, C.T., Wang, H.P., Lin, M.T., Kuo, M.L., and Lin, J.T. 2004. Interleukin-6 increases vascular endothelial growth factor and angiogenesis in gastric carcinoma. J. Biomed. Sci. 11: 517527.

Keller, E.T., Wanagat, J., and Ershler, W.B. 1996. Molecular and cellular 
biology of interleukin-6 and its receptor. Front. Biosci. 1: d340-d357. Kita, K., Saito, S., Morioka, C.Y., and Watanabe, A. 1999. Growth inhibition of human pancreatic cancer cell lines by anti-sense oligonucleotides specific to mutated K-ras genes. Int. J. Cancer 80: $553-$ 558.

Kopf, M., Baumann, H., Freer, G., Freudenberg, M., Lamers, M., Kishimoto, T., Zinkernagel, R., Bluethmann, H., and Kohler, G. 1994. Impaired immune and acute-phase responses in interleukin-6-deficient mice. Nature 368: 339-342.

Lim, K.H. and Counter, C.M. 2005. Reduction in the requirement of oncogenic Ras signaling to activation of PI3K/AKT pathway during tumor maintenance. Cancer Cell 8: 381-392.

Lim, K.H., O'Hayer, K., Adam, S.J., Kendall, S.D., Campbell, P.M., Der, C.J., and Counter, C.M. 2006. Divergent roles for RalA and RalB in malignant growth of human pancreatic carcinoma cells. Curr. Biol. 16: $2385-2394$

Loeffler, S., Fayard, B., Weis, J., and Weissenberger, J. 2005. Interleukin-6 induces transcriptional activation of vascular endothelial growth factor (VEGF) in astrocytes in vivo and regulates VEGF promoter activity in glioblastoma cells via direct interaction between STAT3 and Sp1. Int. J. Cancer 115: 202-213.

Moore, P.S., Sipos, B., Orlandini, S., Sorio, C., Real, F.X., Lemoine, N.R., Gress, T., Bassi, C., Kloppel, G., Kalthoff, H., et al. 2001. Genetic profile of 22 pancreatic carcinoma cell lines. Analysis of K-ras, p53, p16 and DPC4/Smad4. Virchows Arch. 439: 798-802.

Nilsson, M.B., Langley, R.R., and Fidler, I.J. 2005. Interleukin-6, secreted by human ovarian carcinoma cells, is a potent proangiogenic cytokine. Cancer Res. 65: 10794-10800.

O'Hayer, K.M. and Counter, C.M. 2006. A genetically defined normal somatic human cell system to study ras oncogenesis in vitro and in vivo. Methods Enzymol. 407: 637-647.

Podor, T.J., Jirik, F.R., Loskutoff, D.J., Carson, D.A., and Lotz, M. 1989. Human endothelial cells produce IL-6. Lack of responses to exogenous IL-6. Ann. N. Y. Acad. Sci. 557: 374-385.

Quintanilla, M., Brown, K., Ramsden, M., and Balmain, A. 1986. Carcinogen-specific mutation and amplification of Ha-ras during mouse skin carcinogenesis. Nature 322: 78-80.

Romano, M., Sironi, M., Toniatti, C., Polentarutti, N., Fruscella, P., Ghezzi, P., Faggioni, R., Luini, W., van Hinsbergh, V., Sozzani, S., et al. 1997. Role of IL-6 and its soluble receptor in induction of chemokines and leukocyte recruitment. Immunity 6: 315-325.

Rowley, M. and Van Ness, B. 2002. Activation of N-ras and K-ras induced by interleukin-6 in a myeloma cell line: Implications for disease progression and therapeutic response. Oncogene 21: 8769-8775.

Shields, J.M., Pruitt, K., McFall, A., Shaub, A., and Der, C.J. 2000. Understanding Ras: 'It ain't over 'til it's over.' Trends Cell Biol. 10: $147-154$.

Sironi, M., Breviario, F., Proserpio, P., Biondi, A., Vecchi, A., Van Damme, J., Dejana, E., and Mantovani, A. 1989. IL-1 stimulates IL-6 production in endothelial cells. J. Immunol. 142: 549-553.

Smith, P.C. and Keller, E.T. 2001. Anti-interleukin-6 monoclonal antibody induces regression of human prostate cancer xenografts in nude mice. Prostate 48: 47-53.

Sparmann, A. and Bar-Sagi, D. 2004. Ras-induced interleukin-8 expression plays a critical role in tumor growth and angiogenesis. Cancer Cell 6: $447-458$.

Suganuma, M., Okabe, S., Kurusu, M., Iida, N., Ohshima, S., Saeki, Y., Kishimoto, T., and Fujiki, H. 2002. Discrete roles of cytokines, TNF$\alpha$, IL-1, IL-6 in tumor promotion and cell transformation. Int. J. Oncol. 20: 131-136.

Trikha, M., Corringham, R., Klein, B., and Rossi, J.F. 2003. Targeted anti-interleukin-6 monoclonal antibody therapy for cancer: A review of the rationale and clinical evidence. Clin. Cancer Res. 9: $4653-$ 4665.

Wallner, L., Dai, J., Escara-Wilke, J., Zhang, J., Yao, Z., Lu, Y., Trikha, M., Nemeth, J.A., Zaki, M.H., and Keller, E.T. 2006. Inhibition of interleukin-6 with CNTO328, an anti-interleukin-6 monoclonal antibody, inhibits conversion of androgen-dependent prostate cancer to an androgen-independent phenotype in orchiectomized mice. Cancer Res. 66: 3087-3095.

Wei, L.H., Kuo, M.L., Chen, C.A., Chou, C.H., Lai, K.B., Lee, C.N., and Hsieh, C.Y. 2003. Interleukin-6 promotes cervical tumor growth by VEGF-dependent angiogenesis via a STAT3 pathway. Oncogene 22:
$1517-1527$.

Wigmore, S.J., Fearon, K.C., Sangster, K., Maingay, J.P., Garden, O.J., and Ross, J.A. 2002. Cytokine regulation of constitutive production of interleukin- 8 and -6 by human pancreatic cancer cell lines and serum cytokine concentrations in patients with pancreatic cancer. Int. J. Oncol. 21: 881-886. 


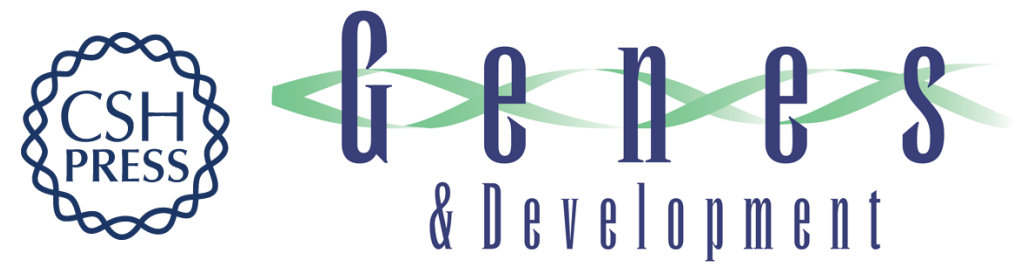

\section{Oncogenic Ras-induced secretion of IL6 is required for tumorigenesis}

Brooke Ancrile, Kian-Huat Lim and Christopher M. Counter

Genes Dev. 2007, 21:

Access the most recent version at doi:10.1101/gad.1549407

\footnotetext{
Supplemental http://genesdev.cshlp.org/content/suppl/2007/07/09/21.14.1714.DC1

Material

Related Content Targeting oncogenic Ras

Ernesto Diaz-Flores and Kevin Shannon

Genes Dev. August , 2007 21: 1989-1992 Oncogenic Ras-Induced Interleukin-6

Promotes Tumor Growth

John F. Foley

Sci. STKE July , 2007 2007: tw258

References This article cites 31 articles, 8 of which can be accessed free at:

http://genesdev.cshlp.org/content/21/14/1714.full.html\#ref-list-1

Articles cited in:

http://genesdev.cshlp.org/content/21/14/1714.full.html\#related-urls

\section{License}

Email Alerting Receive free email alerts when new articles cite this article - sign up in the box at the top Service right corner of the article or click here.
}

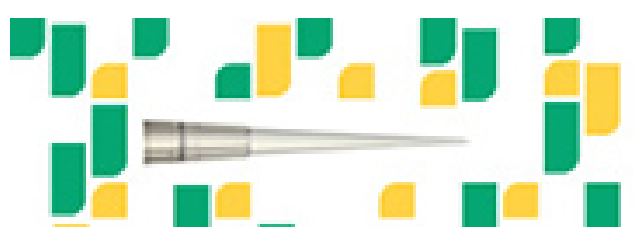

Focused on your science. 